Karolina Follis

Lancaster University

k.follis@lancaster.ac.uk

***Author accepted version 9.04.2019***

\title{
Rejecting Refugees in Illiberal Poland: \\ The response from civil society
}

\begin{abstract}
Since 2015, the European Union and its members have been responding to the increased arrivals of migrants and refugees at Europe's southern shores. The states and societies of East and Central Europe are rarely discussed in this context. Even though their governments support the overall EU policy objectives in the area of freedom, security and justice, they vocally refused to participate in EU 'burden sharing'. In this way these countries earned the label of uniquely xenophobic. This article seeks to complicate this perception by highlighing how civil society in Poland responded to the right-wing Polish government's anti-refugee stance. Through the lens of Aronoff and Kubik's concept of Legal Transparent Civil Society (LTCS) I examine the evolving relationship between the ruling Law and Justice party and civil society organisations, proposing that activities for the benefit of refugees offer an insight into the transformation of civil society in the emerging illiberal political system.
\end{abstract}

Keywords: Poland, refugees, civil society, relocation, foreign aid

\section{Introduction}

The European Union brings together 28, soon to be 27, member states. Of the 27, four have Mediterranean coastlines that are geographically proximate to countries in the Middle East and North Africa from which refugees and migrants headed for Europe have been departing, in fluctuating numbers, for the last twenty years. ${ }^{1}$ The scale of this phenomenon grew in the aftermath of the Arab uprisings in 2011 and the war in Syria to reach unprecedented numbers in 2015 when over one million people arrived 
in Europe by sea. In absence of safe and legal passage to Europe, coastal states have had to cope not just with the logistically daunting task of managing the arrivals of people, but also with the fraught duties of maritime rescue. In that context, they have repeatedly appealed for concerted action at the European level and for support from other members of the European Union. In addition to EU and state level action, we have witnessed a mobilization of civil society involving work by established humanitarian actors as well as transnational activist groups (Rygiel 2016, Cuttitta 2017a, Tazzioli 2016).

But the map of these European activities has distinct blind spots. Largely absent from the recent accounts of responsive action have been the states and societies of East and Central Europe. That is, unless we count the attention given to the vocal opposition of the leaders of Hungary, Poland and Slovakia to the very idea of accepting refugees and to the notion of EU burden sharing in response to the crisis (Murray and Longo 2018). For example, in September of 2015 Hungary attracted the media spotlight as a hostile transit point for refugees on their way from Greece to Northern Europe. These accounts drowned out the stories of ordinary Hungarians involved in grassroots efforts to help those in transit (Kallius et al. 2016, Majtényi et al. 2018). Alongside the news of the anti-immigrant right wing Law and Justice (PiS) party of Jarosław Kaczyński coming to power in Poland in October 2015, such reports revived the stereotypes of backward and intolerant Eastern Europeans who, as Dzenovska put it, "emerged as rogue subjects refusing to "play by the rules"" (Dzenovska 2016, 1). Such narratives however do not tell a complete story. Drawing on research in Poland in 2017 and 2018, this article explores the domestic politics of the refugee crisis, with a particular focus on how civil society organisations (CSOs) responded to the government's closed borders policy. 
One of the intergovernmental responses to the so-called 'migrant crisis' was the establishment of the quota system for refugee relocations, which would see EU member states to accept set numbers of asylum seekers who arrived by sea (Bauböck 2017). The program was designed as a 'solidarity mechanism' to lessen the burden on Italy and Greece (European Council 2015). In Poland, a country of 38 million, it was due to begin in 2016 with the initial admission of 400 people, eventually to accommodate 7200 (Pędziwiatr and Legut 2017). This promise, issued in 2015 by the previous centre-right Prime Minister Ewa Kopacz, was rescinded by the PiS government in March 2016. Seen by Western commentators as an act of insubordination, it subsequently became the subject of a protracted dispute with the European Commission (European Commission 2017). As I show below, the conflict overshadowed the fact that on key matters of border and migration management, the Polish government remains fully aligned with the EU agenda. This agenda, as many scholars have argued, consistently prioritizes border security over the rights of migrants and asylum seekers (Cuttitta 2018). It is against this background that the claims of Eastern Europeans' unique xenophobia deserve critical interrogation. In the years 2016-2017 the non-acceptance of African and Middle Eastern seaborne refugees solidified into an entrenched and popular policy of PiS. ${ }^{2}$ Opinion polls have measured Poles' attitudes towards refugees since mid-2015, when only 21 per cent objected to admitting them to Poland. In December 2017, after nearly two years of sustained official anti-refugee rhetoric, 75 per cent of respondents were against admitting persons fleeing the Middle East and Africa, of whom 52 per cent answered 'definitely not' and 23 per cent 'probably not' (CBOS 2017). To soften the edge of this state sanctioned inhospitality, the government promised to extend Polish foreign aid to refugees in countries of origin and transit, to help address their needs 
'where they are,' thus supposedly discouraging the perilous journeys to Europe. In an interview given in English, the current PM Mateusz Morawiecki called this approach 'assistance in situ,' thus translating the strategically ambiguous Polish phrase pomoc na miejscu. It literally means 'help at the site,' better rendered in English as 'help at the source,' as those who use it do not typically refer to the actual site of conflict but vaguely to the general region. Morawiecki presented such strategic use of foreign aid as an enlightened alternative to what his predecessor Beata Szydło described as the 'folly' of admitting refugees to Europe. ${ }^{3}$

While the country was going through a heightened anti-refugee fever, PiS consolidated its support base and under the slogan of 'the good change,' dobra zmiana, passed legislation dismantling key parts of the liberal democratic order, which had been established in Poland during the postsocialist transition. This entailed political control over the judiciary, suppression of freedom of assembly and attacks on independent media. A growing literature debates whether such developments leave Poland still a democracy, an 'illiberal democracy' or a populist, authoritarian, neoauthoritarian or even fascist state (Fomina and Kucharczyk 2016, Pech and Scheppele 2017, Gdula 2017, Holmes 2016). What emerges from this scholarship and informs this article is the observation that in the new political programme the (putative) 'will of the sovereign' overrides the rule of law and international commitments, particularly those stemming from EU membership.

\section{Civil Society as the Locus of Contestation}

Has the PiS hostile refusal to participate in EU relocations encountered any domestic challenge or pushback? Such opposition may initially seem difficult to locate. Opposition parties (particularly those in Parliament) remained either conspicuously 
silent, or issued meek statements in defence of admitting refugee 'women and children' or 'orphans,' but not men from conflict areas. The Catholic Church, a noted conservative and nationalist force in Polish politics, also fell in line defying its leader Pope Francis on this matter (Cekiera 2017).

Tracing the rare pro-refugee voices in the Polish public sphere back to their sources, I identify civil society as the most likely locus of contestation of the fastspreading anti-refugee convictions. For the purposes of this discussion, I understand civil society broadly as the sphere of association and exchange of ideas beyond the direct control of the state (Goodwin and Jasper 2014, 214). I take what Aronoff and Kubik call the 'convergent approach' between political science and anthropology, conceptualizing civil society as an object of inquiry that can be defined as an ideal type, but remains always historically and geographically situated (Aronoff and Kubik 2014, 202). The authors propose a relatively narrow definition, where civil society consists of legally protected secondary groups characterised by transparency of their activities in public space, and a democratic, deliberative decision-making style. They argue that

The full-fledged, "classic" civil society emerges only when transparent civil society and the legally protected social space coexist; we call it legal transparent civil society (LTCS). ... LTCS is a rare form of social organisation; most social arrangements that are called "civil society" are deficient when compared with this rarely achieved ideal type. (ibid. 204)

In the Polish case, civil society is a sphere that enjoyed a revival after 1989 (Ekiert and Kubik 1999, Jacobsson and Korolczuk 2017). Its role as counterbalance to the state, however, cannot be taken for granted. In Aronoff's and Kubik's model, LTCS 
depends on the state's commitment to the rule of law which protects the autonomy of civic actors. But states that successfully established the rule of law can revert to authoritarianism. Civil society's independence is vulnerable to reversal when states selectively delegalize certain groups or outlaw free associations altogether (ibid., 205). Such changes do not mean however that civil society ceases to exist, only that as the 'L' of LTCS disappears, what emerges are 'hybrid forms of civic and political life' (ibid., 213), such as for example dissident groups devoid of legal protection on the one hand, and authorised associations that operate with the imprimatur of the state on the other. These processes, to a different extent, are under way in Poland and in Hungary. The 2018 'Stop Soros' law in Hungary constitutes an example of the authoritarian regime's attack on critical actors within Hungarian civil society under the pretext of fighting illicit financial transactions. In Poland, with the exception of the well-publicized 2017 police raids on the offices of women's organisations, attacks on civil society have been of a lower profile (Pazderski 2016). The main focus of the government has been to bring NGOs under greater control and to target unwanted activities (support for refugees, women's rights) by means of financial punishment, as explained further in this essay. I ask how have civic actors responded to such changing legal and political environment, and to the political opportunities that arise?

Polish civil society is heterogeneous and includes formally registered organisations (non-governmental organisations or NGOs) funded from public and private sources as well as informal grassroots groups that come together in a lasting or an ad-hoc fashion around a shared public purpose. The sector is active and robust, 'notwithstanding ideological polarization after 2015 [it is] secure, organizationally diverse, relatively well funded from both domestic and external sources, and effectively connected to transnational civil society networks' (Ekiert and Kubik 2017, 
48). Many organisations have a history of working with refugees and migrants, in some cases dating back to the early 1990s, when the state and municipal authorities sought 'social partners' to help address the needs of asylum seekers who arrived in Poland, first from the former Yugoslavia and later from Chechnya and to a lesser extent Georgia, Tajikistan, Belarus and, rarely, other countries in Central Asia and Africa. ${ }^{4}$ This non-profit work has been comparable to the work of NGOs in Western Europe, where civil society organisations support governments in their goals of migrant and refugee integration as well as some aspects of detention and voluntary return (Mayblin and James 2018, Vandevoordt 2016). Such involvement has sometimes prompted critics to interrogate the extent of 'co-option' of voluntary groups into the marketised and repressive system of migration management (Tyler et al. 2014). Such critiques however do not apply in the same way to Poland. The system of migration management is smaller and remains largely in the hands of the state (rather than being outsourced to private actors). Civil society groups provide services which otherwise would not have existed, such as legal aid, language training, job counselling, housing assistance and other forms of support, advocacy and public education. 5

Between June of 2017 and March 2018, I reviewed the work of eleven Warsaw-based civil society organisations involved in migration and refugee affairs domestically and abroad (see Annex). The organisations were selected on the basis of their own self-description and past record as civil society partners of government and local agencies providing services to foreigners in Poland (nine organisations) and to refugees/displaced persons abroad (two organisations). This disproportionate breakdown reflects the division of labour in the sector. Many more NGOs are active domestically than abroad. The latter are organisations classified as providers of 
development and humanitarian aid. Recently, responding to the war in Syria, they began to run programmes for victims of displacement, taking advantage of government funds for 'helping at the source.'

The research focused on Warsaw, which has the highest concentration of foreign citizens of any Polish municipality, estimated at ca. three per cent in a population of 1,75 million at the end of 2015 (Dudkiewicz 2016). ${ }^{6}$ I reviewed three types of data: (a) websites, social media feeds and other materials produced by the CSOs; (b) Polish media coverage of the governments' response to the 'migrant crisis' and that of relevant civic initiatives; (c) eight semi-structured interviews with organisation leaders and activists, on everyday experiences of operating in the altered political climate, from changes to funding and state-NGO relations to dealing with xenophobia. Where I could not speak to organisations directly, I sourced information from public statements, with the acknowledgment that this only partially made up for direct conversations.

Notwithstanding such limitations, the research yielded a complex picture of a civic sector finding itself in a politically, socially and financially unsettled situation. The predicament however is not the same for everyone. There are previously nonexistent opportunities for groups able to work overseas and to provide services in line with the government's policy of 'helping at the source.' Uncertainty concerns primarily groups operating domestically, especially those which for many years have relied on EU funding distributed through ministerial grants. Drawing inspiration from Aronoff and Kubik's LTCS model mentioned above (2013, 205), I conceptualise these differences as backsliding from legally protected civil society towards a hybrid model involving on the one hand 'transparent civil society' (TCS) i.e. officially endorsed associations, and on the other not-yet-quite illegal, but supressed and 
politicised groups that manifestly dissent from official state policy, while connecting to transnational advocacy networks (TANs) (Keck and Sikking 1998). To capture the dynamics of the ensuing activities, I describe civic actors as working along and against the grain of state discourses and practices.

The remainder of the article is divided into two sections. The first shows how PiS has used the spectre of EU relocation as a way to mobilize its supporters by fomenting the fear of a Muslim 'other.' In doing so, Kaczyński's party drew the 'refugee issue' and 'migration crisis' into the centre of political debate. This in turn politicised the question of how Polish society should help refugees, and in consequence also the efforts of civil society organisations involved in such help. The second section of the article illustrates the emerging tensions through a discussion of specific civic activities.

\section{Politics of fear between EU pressures and domestic priorities}

Until 2015, unlike in the West of Europe, migration and refugees did not feature in Polish election campaigns or political party platforms. This changed in the summer of that year when anti-immigrant discourse, in part transnationally linked to the Western far right, and in part sui generis, shifted from the margins into the mainstream. ${ }^{7}$ This happened without a rise in the number of refugees actually arriving in Poland. While the number of foreigners in Poland went up from 193,000 legally resident noncitizens in 2015 to 300,000 in 2017 , this increase is accounted for almost completely by immigration from Ukraine. ${ }^{8}$ The representations of Ukrainians in Poland are also contentious, but to a lesser degree than those of racially different 'others'. ${ }^{9}$ Overall, migration figures remained net negative since 1989 and the numbers applying for international protection averaged at about 8,000 per year in the last decade. 
As I have shown elsewhere, Poland in the postsocialist period has had no meaningful debate on immigration policy (Follis 2012). A signatory of the 1951 Refugee Convention since 1991, it has had a dedicated government agency administering refugee status and subsidiary protection since 1997. It has generally abided by EU law on the Area of Freedom, Security and Justice, such as the Common European Asylum System (CEAS) (Kowalczyk 2014), and applied a laissez-faire approach to workers from Ukraine. The state provides 12 reception centres and rudimentary social benefits for refugee status applicants. NGOs provided assistance drawing on EU integration funds and other foreign and domestic sources, including the Batory Foundation established in 1989 thanks to funding from the financierphilanthropist George Soros. Collaboration between NGOs and the state had highs and lows, but ran along a predictable course (Klaus et al. 2017). Only after PiS's antirefugee rhetoric catapulted the issue into the centre of political debate, immigration came to be seen as a 'problem.'

\section{Relocation and externalisation}

Meanwhile the Polish refusal to cooperate with the EU on relocation received considerable attention in the West. Media outside Poland portrayed the new antirefugee mood as ingratitude on the part of Poles, who were missing an opportunity to repay the EU for the hospitality its members extended to the Poles and for the generous funding of Poland's development. Recalcitrance on relocation, the refusal to extend a helping hand to refugees, was understood as part of a broader deEuropeanising shift, tantamount to 'spitting the EU in the face' (Dempsey 2017).

Dzenovska offers a helpful critique of such 'construction of the Eastern European subject as morally deficient' (Dzenovska 2016, 2) suggesting that the 
European 'civilizing mission of the politics of compassion' (ibid., 9) reproduces the distinction between morally mature Western European subjects and immature, notquite-European Easterners. The perpetuation of this distinction is about reasserting a moral hierarchy which helps obscure the fact that historically and in the present the European humanitarian imperative, or 'the politics of compassion', has been inextricably linked to 'a politics of repression' (Fassin 2005). My findings support a similar contention. While indeed the rise in xenophobia accompanying the refusal was part and parcel of a wider anti-liberal turn, in making sense of the Polish reaction to the 'migrant crisis' I resist the implication that Western states did 'the right thing' by agreeing on relocation, while Eastern Europeans were the non-cooperative villains. What occurred in this case was that the politics of compassion was embodied in the positive valorisation of relocation as an act of 'European solidarity'. The Polish government balked at this framing, demanding the liberty to define compassion as it sees fit, while at the same time subscribing to the politics of repression as currently practiced within the European border regime. Contrary to the dominant narrative of PiS's permanent conflict with Brussels, the position of the Polish government on matters of border and migration management is in fact aligned with that of other member states, and the European Commission. ${ }^{10}$ In concord with the prevailing consensus, PiS supports the ongoing securitization of external European borders as a means of limiting future arrivals by land and by sea. Likewise, the party favours decisive removals of irregular migrants and, judging by official statements on 'helping at the source,' it fully endorses one of the key points of the European Agenda on Migration, that is 'to intervene upstream in regions of origin and of transit' (European Commission 2015, 5). This includes support for the EU-Turkey Agreement of 2016, through payments into the EU Facility for Refugees in Turkey and payments 
into the EU Regional Trust Fund in Response to the Syrian Crisis, which supports assistance initiatives in Jordan, Lebanon and Turkey.

These interventions are elements of deterrent approach to migration from outside the EU. It is a product of a politics of repression, dating back to the 1990s, involving progressive restrictions on access to EU territories through externalizing migratory flows, maximizing the impermeability of EU borders by means of remote control, surveillance of the 'prefrontier' and security cooperation with third countries (Bigo 2014, Casas-Cortes et al. 2015, Zaiotti 2016). ${ }^{11}$ These strategies prevent tens of thousands of people every year from even coming close to European borders, much less crossing them. Hand in hand with these approaches, the EU and the member states have deployed humanitarian and development assistance to improve conditions for refugees in the region, thus facilitating containment (Cuttitta 2017b). ${ }^{12}$ Consistent application of this policy has led to a precipitous drop in maritime arrivals from their height of over 1 million in 2015 to 175 thousand in $2017 .^{13}$

For those who do reach EU territory (Italy, Greece or Spain), Frontex and other EU agencies in cooperation with the member states operate so called 'hotspots' to 'swiftly identify, register and fingerprint incoming migrants,' in some cases for relocation to other EU Member States where their asylum application will be processed (European Commission 2015). However, in spite of the target of 160 thousand people who were to be relocated based on the 2015 plans, as of May 2018 just over 35 thousand benefitted from the program (European Commission 2018).

In light of this trend, the Polish government's objection to relocation was politically significant but practically immaterial. Rallying against the 'imposition' of 'refugee quotas' was a symbolic assertion of sovereignty in the face of what Polish politicians framed as a moralizing politics of virtue driven by the old member states 
of the EU, who seemed to assume that the new member states would simply fall in line. Relocation seemed to force a vision of 'European solidarity,' with which many in Poland could not identify. Instead PiS-affiliated politicians reframed 'Polish solidarity with the EU' as

[t]he continuously growing humanitarian assistance offered primarily (but not exclusively) to persons affected by the Syrian crisis. We also offer significant support to the EU in matters of protecting external EU borders and we nip in the bud recurring attempts to open new [irregular migration] transit routes. (Błaszczak 2017)

The latter point, about shutting down supposed new transit routes, refers to Poland's Eastern border, which at no point during the heightened arrivals of 2015 served as a crossing for Middle Eastern and African refugees, but where for many years persons fleeing Central Asia entered EU territory. The former Minister of Interior, Mariusz Błaszczak (since February 2018 Minister of Defence), linked those arrivals to the 'migrant crisis,' reframing the admission of refugees from a matter of international commitments into one of security policy, which ought to remain the sole prerogative of the nation state. Thus, as part of the anti-refugee turn, Polish Border Guard stopped accepting asylum applications at the eastern border, a point to which I shall return. In sum, the Brussels-Warsaw rift was thus never a dispute over how best to solve the 'migrant crisis' or address the plight of refugees. For the EU as a whole relocation is only a minor and diminishingly important component of an approach to migration based on externalization and containment. To those objectives Poland continuously subscribes. However, the relocation issue created an opening for the European Commission to reprimand a recalcitrant government. In Poland, it represented an opportunity for the right to mobilize voters and reach beyond 
traditional electorate by giving momentum to a politics of fear. Like elsewhere in Europe where anti-immigrant discourses swelled in recent years, Kaczyński’s partisans drew on what Douglas Holmes describes as an 'illiberal political philosophy predicated on the strident discrimination of cultural affinity and difference' (Holmes 2016, 1). According to Ruth Wodak, 'all right wing populist parties instrumentalise some kind of ethnic/religious/linguistic political minority as a scapegoat for most if not all current woes and subsequently construe the respective group as dangerous and a threat "to us," to “our" nation' (Wodak 2015, 2). In Poland, in absence of sizable immigrant communities, Law and Justice instrumentalised a phantom 'other.' PiS encouraged an a priori dread of refugees who have not yet arrived, but who would be, or could be resettled to Poland. Then the party vowed to stop it from happening, thus burnishing their credentials as defenders of the imperilled nation, international commitments be damned. Increasing sections of the public accepted the view that foreigners, especially those who are Muslim or otherwise culturally and/or racially 'other,' are inherently threatening, and that the reason why Poland has not suffered a terrorist attack is because it has no significant Muslim immigrant communities (Hall and Mikulska-Jolles 2016). As such views took hold, long-standing local pro-refugee civil society initiatives and their activists became subject to public censure and targets of attacks.

\section{With and against the Grain}

If the strength of civil society were to be measured by the number of active NGOs, Poland, a country of 38 million, would appear relatively weak in this regard with 70,000 voluntary sector organizations (Adamiak et al. 2016). However, it has been recently argued, 'there is significant potential for robust social activism in Poland,' 
albeit not necessarily captured by traditional categorizations of civic activities (Jacobsson and Korolczuk 2017, 9). The relative strength or weakness of the sector notwithstanding, PiS has shown that it perceives independent civic bodies as a threat to its conservative and centralizing agenda. Since PiS came to power many established organizations have encountered difficulties accessing public funds, to the point that, as my informants reported, many NGOs were forced to lay off staff, terminate long-running programmes or shut down altogether (Klaus et al. 2017). Many organisations have had to adjust to the new circumstances, retreat or develop a strategy of survival.

The notion that actors confronted with situations can work with or against the grain of external facts and ideas has been applied in a variety of contexts, from literature (Bartholomae and Petrosky 1993) to colonial archives (Stoler 2009). For example to understand a text a reader can apply a strategy of reading along the grain, identifying with the author and giving a full consideration to his or her position. A critical approach involves an against the grain strategy, assuming a critical stance, seeking out contradictions, errors and faulty logic. The strategies apply to reading and otherwise engaging with official knowledge, with 'the languages of rule and statist perceptions' (Stoler 2009, 47). Here, the idea illuminates interactions between civil society actors and the government. How does the work of professional advocates and volunteer activists relate to the discourses of the government and its allies, and to the practices of the administrative apparatus of the state? The concept of the grain, and of movements against and along it, alerts us to the possibility that the alignments (with the grain) and tensions (against the grain) between state and civic actors might be a matter of strategy dependent on impermanent alliances and shifting politics, not necessarily fixed ideological commitments. 
In 2015 eight percent of Poland's 70,000 organizations described their area of involvement as 'law, human rights and political activity' and six percent as ‘international activity’ (Adamiak et al. 2016, 80). For both categories refugees and migrants are among the intended beneficiaries. These include services such as legal assistance and intervention, integration support, human and refugee rights advocacy and monitoring and humanitarian assistance to victims of displacement. Additionally, some groups active in the area of 'social services' (21 percent of NGOs) and 'education' (53 percent), provide domestic support to foreigners through language instruction, employment and psychological counselling, workshops and awareness campaigns. With PiS's ascent to power and the spread of its anti-refugee rhetoric, actors working for the benefit of foreign citizens at home found themselves working against the grain of official statements and actions. Those whose activities focus on refugees overseas found themselves not only in alignment with declared state objectives, but also in sudden demand.

\section{Helping at the Source}

An informant representing an umbrella organisation for NGOs involved in humanitarian and development aid bemoaned the fact that,

In the face of the 'migrant crisis' which is really a crisis of values, humanitarian aid became a very convenient method for the government to maintain the pretence of addressing the situation. (Interviewee 1, female)

Indeed, on the one hand, since the beginning of the conflict in Syria, there has been a systematic increase in Polish funding for assistance programs in the Middle East 
(Trojanek and Wnuk 2-17, 2). But the overall size of the aid budget is still regarded as low. According to one report,

The Polish government provides humanitarian aid in two ways: firstly through payments into the EU's international funds (so called multilateral aid, 18.5 million PLN [4.4 million euro] in 2016), and secondly through bilateral aid (16.2 million PLN [3.3 million euro]) where funds are transferred directly to Polish diplomatic outposts abroad and nongovernmental organizations, which compete for Ministry of Foreign Affairs funds. (Trojanek and Wnuk 2017, 2)

Of interest to this article is the bilateral aid, which funds NGOs. In 2016 and 2017 such monies were channelled to Jordan, Lebanon and Iraqi Kurdistan. The Ministry of Foreign Affairs (MFA) does not finance projects in Syria directly. It does so indirectly, through contributions to multilateral funds, arguing that help in Syria would be difficult to monitor and it would endanger aid workers (Trojanek and Wnuk 2017, 2). According to sector insiders, many Polish NGOs are critical of the decision to withhold aid from Syria, noting that Syrian citizens who remain in the country are most in need of humanitarian assistance. These groups have also pointed out that, 'if Poland and Europe hope to limit exodus from Syria, they should contribute by helping at the source, through re-establishing access to water, food and medicines' (ibid.). At least two NGOs, Free Syria and the well-established humanitarian organization Polish Humanitarian Action (PAH) do run programs in Syria, but they do so drawing on private donations and international funds, not government sources. In 2016 governmental funding worth just over 10 million PLN (2.3 million euros) went to four organisations including the Polish branch of the Catholic charity Caritas and the Polish Centre for International Aid (PCPM), a professional humanitarian organisation 
founded in 2005. ${ }^{14}$ Within MFA constraints, Caritas Polska and PCPM have undertaken projects whose beneficiaries are Syrian refugees who left the country, but remain in the region. Caritas, which is involved both overseas and at home is in a unique position, in that on the one hand as a Church-affiliated organisation it is bound by PiS's agenda and its exclusionary nationalist interpretation of Polish Catholicism and Polish identity, and on the other it is compelled to be responsive to the prorefugee advocacy of Pope Francis.

Caritas has used MFA funds to support two clinics in the provinces of Erbil and Dohuk in Iraqi Kurdistan, providing access to medical care to refugees and IDPs in camps and local communities. In Jordan where it has offered housing assistance and supported the social adaptation of Syrian refugees. Apart from these state-funded programmes, since 2015 Caritas has also ran a fundraising campaign called 'Family to Family' (Rodzina rodzinie), which

constitutes a response to Pope Francis' call ... “for a concrete expression of the Gospel and accepting one refugee family in every parish, sanctuary and convent." Thanks to the programme ... every family, community, parish, diocese or organisation can provide direct help to a specific suffering family, accepting them as [people who are] personally close, albeit geographically remote (Caritas n.d., emphasis added).

Through voluntary financial pledges for a period of six months, Polish donor families support named recipients in Syria (Aleppo and surrounding area) who receive the assistance via Caritas' local partners. In this way the state's logic of 'helping at the source' without actually accepting anyone at home gets replicated at the level of citizens. 
PCPM, the other main beneficiary of MFA funding is a secular humanitarian organization whose work for the benefit of the displaced is concentrated primarily in Lebanon, on the border with Syria. ${ }^{15}$ The organisation asserts that its humanitarian aid program there, in operation since 2012, is the largest such program by a Polish NGO (PCPM 2016, 10). The Lebanese government does not permit the establishment of refugee camps and refugees must secure private housing. PCPM provides rent subsidies for refugee families or expenses for host families, medical aid, vocational training, heating devices and blankets in winter, and initiatives related to education, safety and security. Over the course of the first four years of the program, it benefitted over 40 thousand Syrian refugees (ibid.).

PCPM deploys a sophisticated communication strategy, which involves a content-rich and up-to-date website, online videos, and billboards in Polish cities publicising PCPM's activities overseas through what Liisa Malkki called the 'universalizing representational practice' (Malkki 1996, 11) of humanitarian imagery, showcasing women, children, crop harvests and home building. PCPM's founder and director Wojciech Wilk is active on many platforms. A recurring theme in these communications is the argument that the assistance PCPM provides in Lebanon to persons displaced by the conflict in Syria is more economically efficient than helping refugees in Europe. According to Wilk,

Humanitarian assistance in the Middle East is 3-4 times cheaper than that provided to refugees in Poland, and in the case of Germany the difference is colossal. For example, this year's [2017] budget of Humanitarian Appeal, to cover planned activities of the UN and NGOs, which like PCPM, cooperate with the UN, comes to 9 billion dollars for the whole Syrian region. Meanwhile in 2015 ... German expenditure on refugee and migrant welfare 
came to 20 billion euros. Half of that amount would have covered 100 percent of the needs of all the aid programmes in the Middle East. (Dębski 2017)

Wilk's calculations prompt the question whether 'all the aid programmes in the Middle East' indeed constitute the right answer to conflict-related displacement and other socio-economic problems that continue to trigger movements of people. The answer is outside of the scope of this essay, but it bears noting that the implicit criticism of German policy aligns neatly with the position of the Polish government, whose members remain sharply critical of what they called Angela Merkel's 'open door policy.' PCPM meanwhile, for the benefit of the wider public digests Wilk's cost calculations into social media-friendly infographs to show that complex humanitarian aid to eight refugees in Lebanon requires the same means as social benefits for one refugee in Germany. ${ }^{16}$ Working with the grain of PiS policy, PCPM inculcates public recognition of, and pride in the ostensible wisdom of the Polish commitment to 'helping at the source'.

\section{Assistance at Home}

The view that 'helping at the source' is the best, or, more importantly, the only way in which Poland should involve itself in managing the consequences of the 'migrant crisis' is not shared by most of the experienced migrant, refugee and human rights groups. Several informants representing those associations were sharply critical of what they called the government's 'propaganda' on these matters. One informant noted that,

[There] is the ethical problem of creating a [supposed] alternative between helping there and helping here, as if it concerned the same people, while in 
reality there are different people who need different types of assistance, it isn't that [we help] either here or there, one helps where someone needs our help, where we can help that is where we should be helping. (Interviewee 5)

This was echoed by others who condemned the 'false alternative' presented by the government. Informants shared with me details of past and current programs ranging from legal aid to psychological support, job counselling, language courses and integration through sport (cf. Mayblin et al. 2016).

Under PiS such programmes are under threat. The funding regime has changed. For example, in autumn of 2015 organisations entered bids for Ministry of Interior EU Asylum Migration and Integration Fund (AMIF) financing, but the results were never announced and the competition cancelled in April of 2016 (Klaus et al. 2017). Since 2017 these funds are distributed in a new way, via the offices of the voivode (wojewoda), that is regional governors who are normally political nominees. Voivodes were granted the right to choose 'social partners' for the joint realisation of AMIF projects, but thus far there has been little transparency in this process. The sheer fact of involvement in pro-refugee activity is stigmatized in PiS-friendly media as an ostensibly extreme-left (lewacki) project. Pro-refugee efforts are subject to online hate, in milder iterations represented as the 'folly' of political correctness, or more strongly as part of the alleged 'plan to destroy Europe' sponsored by the 'Jewish billionaire George Soros.' Rhetorical attacks on refugees and their supporters went hand in hand with the rapid increase, since the right's ascent to power, in hate crimes against foreigners in Poland (Piela and Łukjanowicz 2018).

On the other hand, new sources of support and ways of organising help to some extent to alleviate the shortfall in funding. As state funding diminished, private 
donations to some organisations have soared. As one informant put it 'people are ashamed for their government' (informant 2, male) and this has mobilised them to volunteer their time and donate directly or through taxes (taxpayers can name an NGO beneficiary who will receive one percent of their total taxes). Such mobilisation includes many Catholics disappointed not just with the government, but also with the Church's failure to condemn xenophobia and embrace the refugee cause.

Organisations are finding new, agile ways of organising outside the formalised NGO system, turning to loose coalitions, social media activism and public awareness campaigns. They merge the Polish experience with that of anti-racist movements in more diverse societies. Like the Greek activists described by Lazaridis and Veikou, they strive to sensitize, 'the public sphere through the diffusion of information on all forms of discrimination, xenophobia and racism, and the organisation of petitions and other protest events' (Lazaridis and Veikou, 2017, 12). They attempt to turn the tide of xenophobia by amplifying alternative narratives, for example through online content linking the struggles of contemporary refugees with the historical experiences of refugees from Poland in the $18^{\text {th }}$ to the $20^{\text {th }}$ century.

Pro-refugee actors work in the interstices of the system against the grain of institutional arrangements, which obstruct access to financing, promote antiimmigrant politics and accept xenophobic violence. They did not have the opportunity to serve the beneficiaries of EU relocations, but they continue to help asylum seekers and immigrants who find their way to Poland in other ways. For example, some recent interventions pushed back against the official idea that Poland's eastern border is on the verge of turning into a new irregular immigration channel. Activists intervened against the treatment of mostly Chechen and Tajik refugees on the border between Poland and Belarus. For years, according to Klaus and colleagues, 'the 
border crossing in Terespol has been the primary location for the majority of applications for international protection submitted in Poland' (Klaus et al. 2018). However, in the context of anti-refugee politics, more and more refugees were denied entry into Poland at this very facility. People intending to apply for refugee status have had their applications withdrawn by the Border Guard on grounds of no valid visa or document on entry. The number of such withdrawals stood at 17,376 between January and September 2015, whereas between January and September 2016 it increased fivefold to 72,528. (ibid.)

Even though the situation had nothing to do with the maritime arrivals in the south of Europe, the conditions on the border deteriorated as families seeking protection, with no means of subsistence and unable to return home camped at the train station in Brest, Belarus. In that context, 'the Interior Minister, Mariusz Błaszczak, in August $2016, \ldots$ opined that Chechens did not need protection since their country was not at war and the situation in Terespol was "testing a new transit route for the influx of Muslim migrants into Europe" (ibid.).

The Association of Legal Intervention ( $\mathrm{SiP})$ has been consistently challenging this new approach in their legal work, outreach activities and publications. One report concludes that 'the practice currently in place violates both international and Polish law and constitutes infringement of human rights' (Chrzanowska et al. 2016, Górczyńska and Szczepanik 2016). SiP, alongside the Helsinki Foundation for Human Rights will now keenly observe and report on the outcome of the June 2017 application to the European Court of Human Rights against Poland by a claimant who was denied entry on the border 28 times (Application no. 40503/17 M.K. against 
Poland, 8 June 2017). The claimant alleges violation of articles 3 (prohibition of torture and inhuman degrading treatment), article 4 of the $4^{\text {th }}$ Protocol (prohibition of collective expulsions), article 13 (effective remedy) and article 34 (disregarding interim measures issued by the court). The claimant's initial application resulted in the Court issuing interim measures ordering Poland to enable him to proceed with the refugee status application. Poland disregarded the interim measures, a situation which SiP described on its website as 'unprecedented.'

\section{Conclusion: Borders, Civil Society and the Politics of the Need to Help}

Since 2015, Polish refugee, migration and human rights advocates operate in a framework of refugee non-admission and 'helping at the source' with its specific administrative practices and legislative changes. CSOs whose mission involves humanitarian and developmental aid overseas are in a position to work with the grain of policy, that is partner with the government to deliver assistance to migrant and refugee beneficiaries in regions of origin and transit. This does not necessarily mean that such groups explicitly endorse the government's political stance. Indeed, in line with an ethos dating back to humanitarianism's $19^{\text {th }}$ century origins, they self-identify as apolitical. However, organisations such as PCPM and Caritas must be prepared that their work might be appropriated to advance the narrative of 'helping at the source' represented as the only remedy for displacement. To be sure, the need for aid to low and middle-income countries that host most of the world's refugees is widely acknowledged by experts. However, the questions of how best to deliver this support, and how it should relate to international protection and resettlement remain subject to complex debates (Amnesty International 2016, UNHCR 2017, Betts and Collier 2016). 
The Polish government's approach ignores those debates and frames foreign aid as a replacement for, rather than parallel to recognizing the right to asylum. The effort to incentivise migrants to stay where they are through 'helping at the source' is articulated in the idiom of traditional overseas humanitarian and development aid, albeit carried out 'under the Polish flag' and informed, like all of Polish involvement in international aid, by Poland's own history of suffering and struggle (DrążkiewiczGrodzicka 2013). As Liisa Malkki observes in her ethnography of Finnish humanitarianism, 'the urge to help faraway others has domestic roots [and it is created by] quite specific characteristics of the home society' (Malkki 2015, 134). In Poland, it is Catholicism that likely shapes the ethical stance of the subject who witnesses mediatised violence experienced by distant others, and may, in some cases, feel a desire to 'do something' to alleviate suffering. Yet the official Church meets this impulse with apathy at best and open hostility at worst. In this situation, the baffled subject welcomes the assurances of the government that it is indeed helping abroad, not only showing generosity without endangering the 'security of Poles,' but also ostensibly acting more wisely than the Germans and other Western Europeans who are said to have made the mistake of admitting too many refugees (Hall and Mikulska-Jolles 2016). Accordingly, the West is now paying the price in the form of high welfare bills and a persistent terror threat, while Poland avoids such problems by refusing to open its borders in the first place. Beyond such domestic appeal, the strategy of publicising Polish foreign aid is intended to elevate Poland as a responsible member of the international community.

With so much political emphasis on non-admission and 'helping at the source,' those civil society organisations whose mission is to help refugees in Poland find themselves censured and ostracised. It would not be accurate to state that their 
legal protections have been revoked, but they have been rendered uncertain. To fulfil their mission, they must work against the grain in the interstices of the system. In doing so, they do not follow a single script. They engage in a politics of compassion by raising awareness of refugee issues and providing legal and social assistance to the relatively small numbers of asylum applicants who do arrive in Poland, but who are not officially welcome. These organizations draw on shrinking resources, as public funding to NGOs is cut off. They take up legal cases to uphold Poland's existing international protection commitments even as the ruling party is pushing for restrictive changes in Poland's refugee laws. They draw on the secular idiom of human and refugee rights, emphasizing universal values, but some among them also offer a reading of history, which mobilizes empathy by highlighting Poles' historical experience of displacement. They also appeal to religious values and look to the figure of Pope Francis over the heads of Polish bishops for ethical guidance on refugee matters. Ultimately, they challenge the exclusionary Polish state to open up and play a more benevolent role in the European response to refugee arrivals.

In spite of these dynamics, a paradox remains. The conflict between Poland and the European Commission over relocation is in fact superficial, in the sense that both sides are united in the overriding commitment to a policy of keeping prospective refugees and migrants away from European borders and territories. The priorities at the heart of the current EU border regime are securitization, containment, deterrence, and aid. Kinship with this approach lends legitimacy to the discourse of 'helping at the source' and helps successive Polish PMs to frame matter the internationally as a reasonable policy choice. Likewise, the efforts to keep Poland's Eastern border closed to asylum seekers are hardly at odds with the current modes of policing at other external EU borders. Seen from this perspective, the contributions of Polish 
civil society engage not only with the pervasive anti-refugee discourse of Kaczynski's illiberal party, but they speak also to the larger externalizing dynamics of the European border regime. As Poland's LTCS gradually loses the 'L,' it moves towards 'hybrid forms' of intersection of domestic/transnational and civil/political. Where ordinary politics abdicates, such hybrids still challenge the state.

\section{Notes}

${ }^{1}$ For up to date quantitative information on the maritime situation see UNHCR data portal at https://data2.unhcr.org/en/situations/mediterranean

${ }^{2}$ On June 14th 2017 the European Commission launched an infringement procedure against Poland (and Hungary and Czechia) 'for non-compliance with obligations under the 2015 Council Decisions on relocation' (European Commission 2017). As of April 2018 those procedures remained ongoing.

${ }^{3}$ The interview with PM Morawiecki by $\mathrm{CNN}$ is available at https://youtu.be/gksyz6s2tvU (accessed 10 May 2018). PM Szydło made her comments following the May 21, 2017 attack in Manchester (https://youtu.be/3BO7C_9xizk accessed 10 May 2018).

${ }^{4}$ Statistics of asylum application filings dating back to 1992, with country of origin are available on the website of the Foreigners Office at https://udsc.gov.pl/statystyki/raporty-okresowe/zestawienia-roczne/ (accessed May 10, 2018). 
${ }^{5}$ Some issues, such as job counseling, language training and other integration measures, are within the competence of local authorities and depending on the local situation local NGOs might be sheltered from national level politics by virtue of operating in a more friendly political environment at the local level (as was the case in Warsaw, ruled by Civic Platform, where I conducted my research).

${ }^{6}$ The actual number is most likely significantly higher, including persons of irregular status and residing in Warsaw temporarily (ibid., 49)

${ }^{7}$ For similar arguments focusing on Islam and islamophobia see Narkowicz and Pędziwiatr 2017.

${ }^{8}$ These figures cover legal residents, i.e. those who granted residence permits (see the statistics of the Foreigners Office available at www.migracje.gov.pl). Estimates say that there are over 1 million Ukrainian citizens in Poland owing to a liberal system of work visas, which PiS spokespersons have sought to represent as a way in which Poland 'helps Ukrainian refugees' (see e.g. OKO.press 2016).

${ }^{9}$ Ukrainians in Poland occupy the treacherous position of 'culturally proximate', relatively desirable economic migrants who, unprotected in the labor market, 'do the work no one else wants to do' (Follis 2012). As we know from the examples of other migrant receiving societies, shifting politics can rapidly turn such perceptions into accusations of 'job stealing' and violent hostility (Rzepnikowska 2017, see also Apostolova 2016).

${ }^{10}$ Kallius makes a similar argument in relation to the Hungarian policy of fencebuilding around its borders (Kallius 2017).

${ }^{11}$ On the historical evolution of the EU border regime, see e.g. Van Houtum 2010, Neal 2009. 
${ }^{12}$ It must be said that budgets for security far exceed humanitarian expenditure. In 2017 the EU earmarked 6 billion Euros for tackling the 'migration crisis' and border security while 1 billion was reserved for humanitarian aid across all regions (European Commission 2017).

${ }^{13}$ See $n 1$

${ }^{14}$ The other ones were Polish Medical Mission and Free Syria which received minor funding.

${ }^{15}$ Helping Syrian refugees is one part of PCPM's portfolio. Other programmes run in Kenya, Georgia, Ukraine and Palestine and South Sudan.

${ }^{16}$ See http://pcpm.org.pl/pomoc-humanitarna/liban-pomoc-dla-uchodzcow-syryjskich 


\section{References}

Adamiak, P., Charycka, B. \& Gumkowska, M. (2016). Kondycja sektora organizacji pozarzadowych $w$ Polsce, 2015. [The Condition of the NGO Sector in Poland, 2015.] Warszawa: Stowarzyszenie Klon/Jawor.

Amnesty International. (2016). Tackling The Global Refugee Crisis. From Shirking to Sharing Responsibility. London: Amnesty International.

Apostolova, R. (2016). The Real Appearance of the Economic/Political Binary: Claiming Asylum in Bulgaria. Intersections: East European Journal of Socity and Politics 2(4): 34-50.

Aronoff, M. J. \& Kubik, J. (2014) Anthropology \& Political Science. A Convergent Approach. London and NY: Berghahn.

Bartholomae, D. \& Petrosky, A. (1993). Ways of Reading: An Anthology for Writers. Boston, MA: St. Martin's Press.

Bauböck, R. (2018) Refugee Protection and Burden-Sharing in the European Union. JCMS: Journal of Common Market Studies 56(1): 141-156.

Betts, A. \& Collier, P. (2017). Refuge: transforming a broken refugee system, London: Allen Lane.

Bigo, D. (2014). The (in)securitization practices of the three universes of EU border control: Military/Navy - border guards/police - database analysts. Security Dialogue 45(3): 209-225.

Błaszczak, M. (2017, August 28). Nie uczcie nas solidarności [Do not teach us solidarity]. Retrieved from http://www.rp.pl/

Caritas. (n.d.). Sytuacja uchodźców syryjskich. [The situation of Syrian refugees.] Retrieved from http://rodzinarodzinie.caritas.pl/faq/

Casas-Cortes, M., Cobarrubias, S. \& Pickles, J. (2015) Riding Routes and Itinerant Borders: Autonomy of Migration and Border Externalization. Antipode 47(4): 894914.

Centrum Badania Opinii Spolecznej. (2017). Komunikat z badań Nr. 163/2017. Stosunek do przyjmowania uchodźców [Communique on Study Results No. 163/2017. Attitudes towards accepting refugees.] Warszawa: Author.

Cekiera, R. (2017). Między gościnnością a misoksenią - reperkusje kryzysu migracyjnego w Polsce [Between hospitality and misoxenia - aftershocks of the migration crisis in Poland], Political Preferences, 17: 237-250.

Cuttitta, P. (2017). Mapping Humanitarian Non-State Actors of Migration Management in Tunisia, Libya and Egypt. Paper presented at the 24th International Conference of Europeanists, Glasgow, July 12.

Cuttitta, P. (2017). Repoliticization Through Search and Rescue? Humanitarian NGos and Migration management in the Central Mediterranean. Geopolitics, Online First https://doi.org/10.1080/14650045.2017.1344834

Cuttitta, P. (2018) Pushing Migrants Back to Libya, Persecuting Rescue NGOs: The End of the Humanitarian Turn (Part I). Retrieved from: https://www.law.ox.ac.uk/research-subject-groups/centrecriminology/centreborder-criminologies/blog/2018/04/pushing-migrants 
Dębski, S. (2017). Konwoje wyglądają lepiej w świetle kamer. Rozmowa z prezesem Fundacji Polskie Centrum Pomocy Międzynarodowej Wojciechem Wilkiem. [Convoys look better on camera. Conversation with Wojciech Wilk, head of the PCPM Foundation], Polski Przeglad Dyplomatyczny 2: 19-32.

Dempsey, J. (2017). Europe. Wake UP! Sleep Walking is Over. Keynote Address delivered at the $24^{\text {th }}$ International Conference of Europeanists, Glasgow, July 12.

Drążkiewicz-Grodzicka, E. (2013). From Recipient to Donor: The Case of Polish Developmental Cooperation. Human Organization 72 (1): 65-75.

Dudkiewicz, M. (Ed.) (2016). Cudzoziemcy w Warszawie, czyli jak zmierzyć się z nieuniknionym. Raport. [Foreigners in Warsaw, or how to confront the inevitable. Report]. Warszawa: Fundacja Obserwatorium.

Dzenovska, D. (2016) "Eastern Europe, the Moral Subject of the Migration/Refugee Crisis, and Political Futures." Near Futures Online 1 "Europe at a Crossroads" Retrieved from: http://nearfuturesonline.org/eastern-europe-the-moral-subject-ofthe-migrationrefugee-crisis-and-political-futures/

Ekiert, G. \& Kubik, J. (2017). Civil Society in Postcommunist Europe. Poland in a Comparative Perspective, In Jacobsson, K. \& Korolczuk, E. (Eds.), Civil Society Revisited: Lessons from Poland. Oxford: Berghahn Books.

European Commission. (2015). A European Agenda on Migration. Retrieved from http://ec.europa.eu/dgs/home-affairs/what-we-do/policies/european-agendamigration/background-

information/docs/communication_on_the_european_agenda_on_migration_en.pdf

European Commission. (2017). Relocation: Commission launches infringement procedures against the Czech Republic, Hungary and Poland. Retrieved from http://europa.eu/rapid/press-release_IP-17-1607_en.htm.

European Commission. (2017). Funding for Humanitarian Aid, Retrieved from http://ec.europa.eu/echo/funding-evaluations/funding-humanitarian-aid_en

European Commission. (2017). The Hotspot Approach to Managing Exceptional Migratory Flows. Retrieved from https://ec.europa.eu/homeaffairs/sites/homeaffairs/files/what-we-do/policies/european-agendamigration/background-information/docs/2_hotspots_en.pdf

European Commission. (2018). Member States' Support to Emergency Relocation Mechanism (As of April 2018). Retrieved from https://ec.europa.eu/homeaffairs/sites/homeaffairs/files/what-we-do/policies/european-agendamigration/press-material/docs/state_of_play_-_relocation_en.pdf

European Council. (2015), Council Decision (EU) 2015/1601 of 22 September 2015 establishing provisional measures in the area of international protection for the benefit of Italy and Greece, Retrieved from http://eurlex.europa.eu/eli/dec/2015/1601/oj.

Fomina, J. \& Kucharczyk, J. (2016). Populism and Protest in Poland, Journal of Democracy 27(4): 58-68.

Gdula, M., (2017). Dobra Zmiana w Miastku. Neoautorytaryzm w polskiej polityce z perspektywy małego miasta. [The Good Change in Miastko. Neoauthoritarianism in Polish Politics. A Small Town Perspective], Warszawa: Krytyka Polityczna. 
Goodwin, J. and Jasper, J.M.. (2015). The social movements reader: Cases and concepts (Third ed.). Chichester: Wiley/Blackwell.

Górczyńska, M. and Szczepanik, M. (2016). Droga donikąd. Relacja z wizyty monitoringowej na białorusko-polskim przejściu granicznym Brześć-Terespol. [The Road to Nowhere. Report on a visit to the Polish-Belorussian border crossing Brest-Terespol.] Warszawa: Helsinki Foundation for Human Rights.

Hall, D. \& Mikulska-Jolles, A. (2016). Uprzedzenia, starch czy niewiedza? Mlodzi Polacy o powodach niecheci do przyjmowania uchodzcow. [Prejudice, fear or ignorance? Young Poles on the reasons for unwillingness to accept refugees]. Analizy, Raporty, Expertyzy 1/2016. Warszawa: Stowarzyszenie Interwencji Prawnej

Holmes, D. R. 2016. Fascism 2. Anthropology Today 32(2): 1-3.

Holmes, S.M. \& Castañeda, H. (2016). Representing the "European refugee crisis" in Germany and beyond. American Ethnologist 43(1): 12-24.

Jacobsson, K. Korolczuk, E. (Eds). (2017). Civil Society Revisited: Lessons from Poland. Oxford: Berghahn Books.

Kallius, A. (2017) The Speaking Fence. Anthropology Now 9(3): 16-23.

Kallius, A., Monterescu, D. Rajaram, P.K. (2016), Immobilizing mobility: Border ethnography, illiberal democracy, and the politics of the "refugee crisis" in Hungary. American Ethnologist 43(1): 25-37.

Klaus, W., Lévay, M., Rzeplinska, I. and Scheinost, M. (2018). Refugees and asylum seekers in Central-European Countries - reality, politics and the creation of fear in societies, In H. Kury and S. Redo (Eds.) Refugee Law and Policy. Challenges and Opportunities for Global Civic Education, Basel: Springer.

Klaus, W., Ostaszewska-Żuk, E. and Szczepanik, M. (2017). Fundusze europejskie $i$ ich rola we wspieraniu integracji cudzoziemców w Polsce. [European Funds and Their Role in Supporting the Integration of Migrants in Poland]. Warszawa: Helsinki Foundation for Human Rights.

Kowalczyk, B. (2014). Polski system azylowy. [The Polish Asylum System], Wrocław: Uniwersytet Wrocławski.

Lazaridis, G. \& Veikou, M. The rise of the far right in Greece and opposition to 'othering,' hate speech, and crime by civil and civic organisations. Journal of Civil Society, 13:1, 1-17.

Malkki, L. (2015). The Need to Help: The domestic arts of international humanitarianism, Durham, NC: Duke University Press.

Malkki, L. (1996). Speechless Emissaries: Refugees, Humanitarianism, and Dehistoricization. Cultural Anthropology, 11(3): 377-404.

Majtényi, B., Kopper, A. \& Susanszky, P. (2019). Constitutional Othering, Ambiguity and Subjective Risks of Mobilization in Hungary: Examples from the Migration Crisis. Democratization, 26 (2): 173-189.

Mayblin, L., Valentine, G. \& Winiarska, A. (2016). Migration and diversity in a postsocialist context: Creating integrative encounters in Poland. Environment and Planning A, 48(5), 960-978. 
Mayblin, L. \& James, P. (2018). Asylum and refugee support in the UK: civil society filling the gaps? Journal of Ethnic and Migration Studies, Advance online publication DOI: 10.1080/1369183X.2018.1466695

Murray, P. \& Longo, M. (2018). Europe's Wicked Legitimacy Crisis: The Case of Refugees. Journal of European Integration, 1-15.

Narkowicz, K. \& Pędziwiatr, K. (2017). From unproblematic to contentious: Mosques in Poland. Journal of Ethnic and Migration Studies, 43(3), 441-457.

Neal, Andrew (2009). Securitization and Risk at the EU Border: The Origins of FRONTEX, JCMS 47(2), 333-356.

OKO.press. (2016, November 7). Kaczyński pomylił się 50 tysięcy razy. Z Ukrainy przyjęliśmy nie milion, lecz 20 uchodźców. [Kaczyński erred by 50 thousand times. We accepted twenty, not one million refugees from Ukraine], Retrieved from https://oko.press/

OKO.press. (2018, January 27). "Na IPN wydajemy dwa i pół raza więcej niż na 'pomoc na miejscu.' [We spend two and a half times more on the Institute for Public Remembrance than on 'helping at the source.'] Retrieved from https://oko.press/

Pazderski, F. (2016). Poland: Expecting Negative Trends, In E. Belokurova (Ed.) 2016 Report on the State of Civil Society in the EU and Russia, Berlin: EU-Russia Civil Society Forum.

Polskie Centrum Pomocy Międzynarodowej. (2016). Raport merytoryczny za rok 2016 [Report of Activities for 2016] Retrieved from http://pcpm.org.pl/polskiecentrum-pomocy-miedzynarodowej/raporty-pcpm

Pech, L. \& Scheppele, K.L. (2017). Illiberalism Within: Rule of Law Backsliding in the EU. Cambridge Yearbook of European Legal Studies 19: 3-47.

Pędziwiatr, K. and Legut, A. (2017). Polskie rządy wobec unijnej strategii na rzecz przeciwdziałania kryzysowi migracyjnemu. [Polish governments on the European strategy of dealing with the migration crisis.] In J. Wojtaszczyk and J. Szymańska (Eds.) Uchodźcy w Europie, Warsaw: Warsaw University Press.

Piela, A. \& Łukjanowicz, A. (2018). Islamophobia in Poland: National Report 2017, In E. Bayraklı \& F. Hafez (Eds.) European Islamophobia Report 2017. Istanbul: SETA.

Rijpma, J. \& Vermeulen, M. (2015). EUROSUR: saving lives or building borders? European security, 24(3), 454-472.

Rygiel, K. (2016). Dying to live: migrant deaths and citizenship politics along European borders. Citizenship Studies 20(5):545-560.

Rzepnikowska, A. (2019) Racism and xenophobia experienced by Polish migrants in the UK before and after Brexit vote. Journal of Ethnic and Migration Studies 45(1): 61-77.

Stoler, A. L. (2009). Along the archival grain: Epistemic anxieties and colonial common sense. Princeton, N.J.: Princeton University Press.

Tazzioli, M. (2016). Eurosur, Humanitarian Visibility, and (Nearly) Real-time Mapping in the Mediterranean. ACME: An International Journal for Critical Geographies, 15(3): 561-579. 
Trojanek, M. \& Wnuk, M. (2017). Jeśli nie w Polsce to gdzie rząd pomaga uchodźcom z Syrii? [If not in Poland than where does the government help refugees from Syria?], Warszawa: Grupa Zagranica.

Tyler, I., Gill, N. Conlon, D. \& Oeppen, C. (2014). The business of child detention: Charitable co-option, migrant advocacy and activist outrage. Race \& Class, 56(1): 3-21.

UNHCR. (2017). UNHCR Global Appeal 2018-2019 - Building better futures, Retrieved from http://www.unhcr.org/uk/publications/fundraising/5a0c02ab7/unhcr-global-appeal2018-2019-building-better-futures.html

Vandevoordt, R. (2016). Between humanitarian assistance and migration management: on civil actors' role in voluntary return from Belgium, Journal of Ethnic and Migration Studies, 43(11):1907-1922.

van Houtum, H. (2010). Human Blacklisting: The Global Apartheid of the EU's External Border Regime. Environment and Planning D: Society and Space, 28(6): 957-976.

Wodak, R. (2015). The politics of fear: What right-wing populist discourses mean. Los Angeles: SAGE.

Zaiotti, R. (Ed.) (2016). Externalizing migration management: Europe, North America and the spread of 'remote control' practices, London: Routledge. 